\title{
A Rare Congenital Biliary Anomaly: Anomalous Pancreaticobiliary Junction
}

\section{Nadir Bir Konjenital Safra Anomalisi: Pankreatikobiliyer Bilişim Anomalisi}

\author{
(1)Hilal Er Ulubaba', @idris Kirhan², @Rukiye Ciftci ${ }^{3}$ \\ 'Yeşilyurt Hasan Çalık Public Hospital, Clinic of Radiology, Malatya, Turkey \\ ${ }^{2}$ Harran University Faculty of Medicine, Internal Medicine, Şanlıurfa, Turkey \\ 3ंnönü University, Faculty of Medicine, Physical Medicine and Rehabilitation, Malatya, Turkey \\ Copyright@Author(s) - Available online at www.dergipark.org.tr/tr/pub/medr \\ Content of this journal is licensed under a Creative Commons Attribution-NonCommercial 4.0 International License.
}

\begin{abstract}
20 -year-old female patient was admitted with complaints of girdle-like abdominal pain, nausea and vomiting. A history of pancreatitis 2 years ago was found in the patient's anamnesis. Physical examination showed tenderness in the epigastric region, other system examinations were normal. In laboratory tests, amylase was found as $1249 \mathrm{lu} / \mathrm{l}$, lipase was found as $1068 \mathrm{u} / \mathrm{l}$, CRP (C-Reaktif Protein) was found as $49.83 \mathrm{mg} / \mathrm{l}$ and they were found to be high. Liver function tests, kidney function tests and electrolytes were found to be normal. In the abdomen ultrasonography, pancreas was reported to have increased size and mild edema. The patient was hospitalized with these findings and intravenous fluid replacement was started. Magnetic resonance cholangiopancreatography (MRCP) was performed on the patient whose vital findings were stable. MRCP showed that common bile duct and pancreatic duct were joined at $17 \mathrm{~mm}$ proximal from the normal anatomic location. Anomalous pancreaticobiliary junction (APBJ) is a rare congenital anomaly and in recent years its diagnosis frequency has increased due to the widespread use of advanced radiological examinations such as MRCP. The purpose of this case presentation was to present the APBJ that we detected with MRCP in a patient with recurrent pancreatitis attacks.
\end{abstract}

Key Words: Pancreaticobiliary junction; congenital anomaly; pancreatitis; Magnetic resonance cholangiopancreatography

Öz

20 yaşında kadın hasta kuşak tarzında karın ağrısı, bulantı ve kusma şikayetleri ile başvurdu. Hastanın özgeçmişinde 2 yı önce geçirilen pankreatit öyküsü tespit edildi. Fizik muayenesinde epigastrik bölgede hassasiyet saptanıp, diğer sistem muayeneleri normaldi. Laboratuvar incelemelerinde; Amilaz 1249 ıu/l, Lipaz 1068 u/I CRP 49.83mg/l olup yüksek tespit edildi. Karaciğer fonksiyon testleri, böbrek fonksiyon testleri ve elektrolitleri normaldi. Abdomen ultrasonografisinde pankreas boyutu artmış ve hafif ödemli rapor edildi. Bu bulgularla hasta yatırılıp intravenöz sıvı replasmanı başlandı. Vital bulguları stabil olan hastaya MRCP yapıldı. MRCP'sinde; ortak safra kanalı ile pankreatik kanalın normal anatomik lokalizasyondan $17 \mathrm{~mm}$ proksimal kesimde birleştiği tespit edildi. Pankreatikobiliyer bileşim (PBA) anomalisi nadir tespit edilen bir konjenital anomali olup, son yıllarda MRCP gibi ileri radyolojik tetkiklerin yaygın olarak kullanımı nedeniyle tanı sıkığı artmaktadır. Tekrarlayan pankreatit atakları olan hastada, manyetik rezonans kolanjiyopankreatografı (MRCP) ile saptadığımız pankreatikobiliyer birleşim anomalisi (PBA)' ni sunmayı amaçladık.

Anahtar Kelimeler. Pankreatikobiliyer bileşim; konjenital anomali, pankreatit; manyetik rezonans kolanjiyopankreatografı

\section{INTRODUCTION}

Pancreatic duct and common bile duct open to the second part of the duodenum by a short common canal, usually $1-12 \mathrm{~mm}$ in length (1). The normal length of this canal being longer than $15 \mathrm{~mm}$ is a congenital malformation and it is called anomalous pancreaticobiliary junction (APBJ). APBJ is a congenital malformation where the pancreas and bile ducts join outside the duodenal wall, often forming a long common duct. Since the effect of 
Oddi sphincter does not regulate the function of the pancreaticobiliary junction in patients with APBJ, bilateral insufficiency occurs. In this case, it is thought that pancreatic enzymes may pass to common bile duct and bile secretion to pancreatic duct and may cause frequent pancreatitis attacks $(2,3)$. Its prevalence was found as $0.03 \%$ in autopsy series in Japan. It is estimated to be lower in Western societies $(4,5)$. Congenital ABPJ affects women in general and its prevalence rate is 3:1 in men and women (3). It is mostly diagnosed in childhood and in a single centred study conducted in our country by Aksu et al., its prevalence was found as $14.7 \%$ in children with acute recurrent pancreatitis and chronic pancreatitis (6).

In this case report, our aim was to present a case who was admitted with pancreatitis attack and was found to have ABPJ.

\section{CASE REPORT}

20-year-old female patient was admitted to the emergency service with complaints of girdle-like abdominal pain, nausea and vomiting. A history of pancreatitis 2 years ago that required hospitalized treatment was found in the patient's anamnesis. Physical examination showed tenderness in the epigastric region, other system examinations were found to be normal. In laboratory tests, white blood cell ( $\mathrm{wbc}$ ) was found as 7,799 cell/ $\mathrm{mm} 3$, hematocrit was found as $39,63 \%$, hemoglobin was found as $13,13 \mathrm{~g} / \mathrm{dl}$, amylase was found as 1249 Iu/l, lipase was found as $1068 \mathrm{u} / \mathrm{l}$, CRP was found as $49.83 \mathrm{mg} / \mathrm{l}$. Liver function tests, kidney function tests and electrolytes were found to be normal, mild edema was reported in the pancreas in abdomen ultrasonography. The patient was hospitalized with these findings and intravenous fluid replacement was started. The patient's pain and nausea responded to palliative treatment and fluid replacement and decreased. Magnetic resonance cholangiopancreatography (MRCP) was performed on the patient whose vital findings were stable. MRCP showed that common bile duct and pancreatic duct were joined at $17 \mathrm{~mm}$ proximal from the normal anatomic location. In addition, significant narrowing was found in the distal part of choledochus and dilatation was found in the intrahepatic-extrahepatic bile ducts and pancreatic duct (Figure 1).

Dynamic magnetic resonance imaging (MRI) of the liver was performed to exclude periampullary tumour. In MRI, the head part of the pancreas and the second part of the duodenum were normal and minimal wall thickness and increased enhancement was detected in the distal choledochus and it was thought to be due to previous cholangitis attack (Figure 2). In the MRCP performed three months after medical treatment, dilatation in the bile ducts and pancreatic duct was found to be significantly reduced. The patient was discussed in the gastroenterologygeneral surgery-radiology council and surgical operation was recommended in terms of hepatico-jejunostomy.

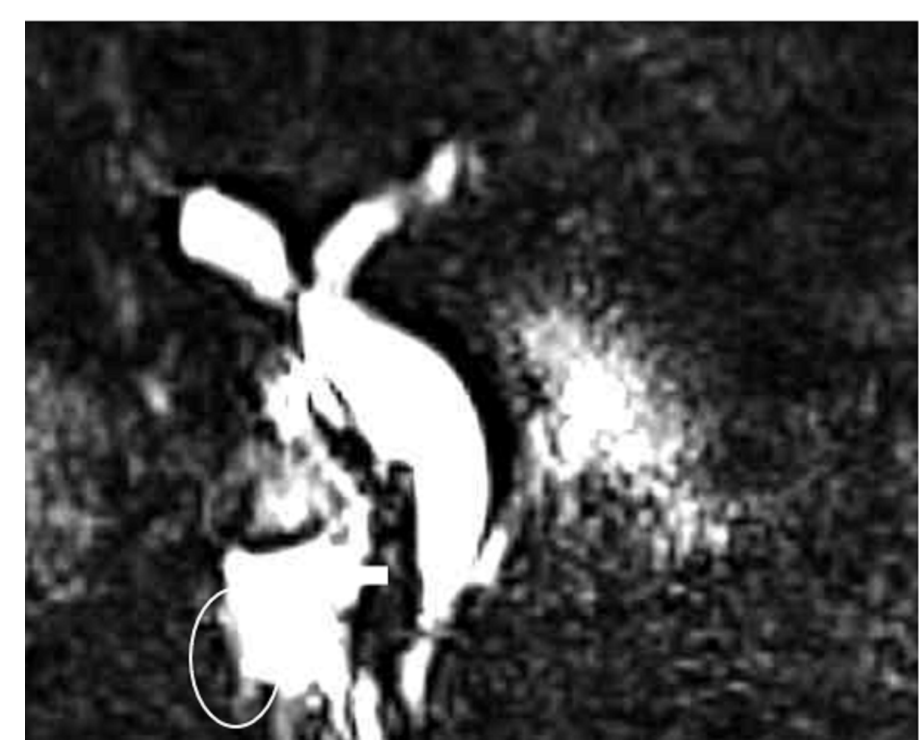

Figure 1. Magnetic resonance cholangiopancreatography (MRCP) image. The connection of the main pancreatic duct with the common bile duct is observed from the proximal of the normal anatomic location (white arrow). $17 \mathrm{~mm}$ long common duct is shown in white circle. The bile ducts and main pancreatic duct are dilated.

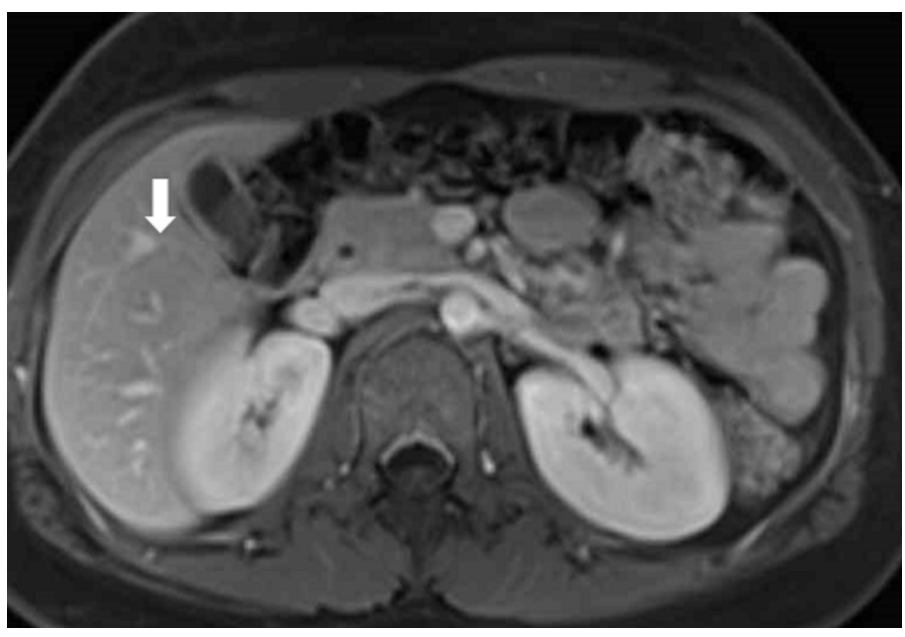

Figure 2. Contrast enhanced axial T1 sequence image. Wall thickening and increased contrast enhancement are observed in the distal choledochus.

\section{DISCUSSION}

APBJ is a rare congenital anomaly and the frequency of diagnosis has increased due to the widespread use of advanced radiological examinations such as MRCP in recent years. APBJ is associated with pancreatitis and bile duct stones affecting $17.9 \%$ of the patients with biliary dilatation and $27.3 \%$ of the patients without biliary dilatation (7). Since the movement of the sphincter does not affect the union functionally, bidirectional deficiency occurs, allowing pancreatic juice to flow back into the common bile duct and bile juice into the pancreatic duct. In patients with APBJ, pancreaticobiliary reflux often causes biliary cancer, biliopancreatic reflux often causes acute or chronic pancreatitis. Bile ducts 
of APBJ patients are considered premalignant and prophylactic surgery is recommended as soon as the diagnosis is made (7-9). In ERCP (endoscopic retrograde cholangiopancreotography), a long common duct, an abnormal bile-pancreatic duct junction and a contraction sphincter distal to the union are features of APBJ. These findings increase the likelihood of comorbid gallbladder carcinoma or an increased risk of developing gallbladder carcinoma. In a study conducted by Hu et al. on APBJ patients in China population, it was found that APBJ patients were younger than individuals who were not APBJ patients. Our case supports the results of this study (2).

APBJ is generally seen in childhood and can rarely be found in adults, as in our case. The widespread use of advanced examinations such as MRCP and ERCP has a great role in making this diagnosis. APBJ should come to mind in patients with frequent pancreatitis attacks; these patients should be diagnosed early and directed to relevant departments to arrange their future treatment.

This case report was presented as an oral presentation at the 3rd Gastrointestinal Research Congress (September, 21-22 2019).

Financial disclosures: All authors report no financial interests or potential conflicts of interest.

Conflict of Interest: The authors declare that they have no competing interest.

Informed Consent: Informed consent was taken from the patient.

\section{REFERENCES}

1. Kamisawa T, Takuma K. Endoscopic diagnosis of pancreaticobiliary maljunction. World J Gastrointest Endosc
2011;3:1.

2. Hu, B., Gong, B., \& Zhou, DY. Association of anomalous pancreaticobiliary ductal junction with gallbladder carcinoma in Chinese patients: an ERCP study. Gastrointest Endosc 2003;57:541-54- 5.

3. Kamisawa, T., Kaneko, K., Itoi, T. Pancreaticobiliary maljunction and congenital biliary dilatation. The Lancet Gastroenterol Hepatol 2017;2:610-8.

4. Miyano T, Yamataka A. Choledochal cysts. Curr Opin Pediatr 1997;9:283-88.

5. Kim HJ, Kim MH, Lee SK. Normal structure, variations, and anomalies of the pancreaticobiliary ducts of Koreans: a nationwide cooperative prospective study. Gastrointest Endosc 2002;55:889-96.

6. Aksu, AÜ., Sarı, S., Gürkan, ÖE. Türk çocuklarda pankreatit: Tek merkez deneyimi. Cukurova Med J 2019;44:991-8.

7. Kamisawa, T., Ando, H., Suyama, M., Shimada, M., Morine, Y., Shimada, H., \& Working Committee of Clinical Practice Guidelines for Pancreaticobiliary Maljunction. Japanese clinical practice guidelines for pancreaticobiliary maljunction. J Gastroenterol 2012;47:731-59.

8. Fukuzawa H, Kajihara K, Tajikawa T, et al. Mechanism of pancreatic juice reflux in pancreaticobiliary maljunction: A fluid dynamics model experiment. J Hepato Biliary Pancreatic Sci 2020;27:265-72.

9. Anderson, S. W., Zajick, D., Lucey, BC., \& Soto, J. A. 64-detector row computed tomography: an improved tool for evaluating the biliary and pancreatic ducts?. Current Problems Diagnostic Radiol 2007;36:258-71. 